\title{
Information and Communication Technology, Bank Verification Number and Fraud Prevention in Nigerian Banking Industry
}

\author{
Odusina Ayokunle $\mathrm{O}^{1 *}$, Fowosire, Remilekun $\mathrm{A}^{2}$ \\ 1Department of Banking and Finance, Abraham Adesanya Polytechnic, ljebu lgbo, Ogun State, Nigeria \\ 2Department of Electrical and Electronics Engineering, Abraham Adesanya Polytechnic, ljebu Igbo, Ogun State, Nigeria \\ ${ }^{*}$ Corresponding Author \\ Odusina Ayokunle 0
}

Article History

Received: 06.07.2019

Accepted: 25.07 .2019

Published: 30.07 .2019

\begin{abstract}
Fraud was cited as Nigeria's biggest problem both in the public and private sector. It is worrisome to note that bank staffs connive with outsiders to perpetrate fraud, even the emergence of ICT recently makes it easy to perpetrate fraud and it was also established that fraud contributed immensely to failure of most banks. Fraud is not peculiar either in magnitude or sophistication to Nigeria, the crash in the multinational companies in the wake of fraud and accounting scandals attests to this fact. Banks nonetheless played a dubious role in the collapse of these corporations. Structured questionnaire was prepared to get the opinions of both workers and bank customers using all the banking industry in Nigeria. This paper endeavors to examine Information Communication Technology, Bank Verification Number and Fraud Prevention in the Banking industry in Nigeria, their responses were critically analyzed and the study concluded that the introduction of Bank Verification Number with the aid of Information communication technology (ICT) is an effective tool that will reduce the incidence of fraud to the barest minimum in Nigeria, the use of ICT should also be encouraged but with strict security and thus the financial institutions and their business partner must continue to seek and develop new solutions to the issue of customer authentication and transaction validation.
\end{abstract}

Keywords: Information Communication Technology, Bank Verification Number, Fraud Prevention, Banking Industry, Nigeria

\section{INTRODUCTION}

The banking sector has become one of the most critical sectors and commanding heights of the Nigerian economy with the wide implications on the level and direction of economic growth and transformation of Nigeria. But unfortunately, the much respected cherished and time valued integrity and survivability of the basic functions of the Nigerian Banking Industry have been called to question due to the unethical practices such like incessant frauds and accounting scandals [1]. Adeyemo [2], opined that the incessant frauds in the Nigerian Banking Industry has lately become a source of embarrassment to the nation, as apparent in the seeming attempts of the law enforcement agencies to successfully track down the culprits.

Fraud is defined according to Agwu [3] is any illegal act characterized by deceit, concealment, or violation of trust. Bank fraud is said to be a case when a person knowingly executes, or attempts to execute, a scheme or artifice to defraud a financial institutions; or to obtain any of the moneys, funds, credits, assets, securities, or other property owned by or under the custody or control of, a financial institution, by means of false or fraudulent pretenses, representations, or promises.

The fight against fraudulent activities through Bank Verification Number (BVN) is of crucial importance to financial service institutions. Not only does it affect their business, but it also has a significant impact on consumers in particular and the economy at large. Furthermore, banking fraud hurts both banks and their customers. Banks incur substantial operating costs by refunding customers' monetary losses [4], while bank customers experience considerable time and emotional losses. They have to detect the fraudulent transactions, communicate them to their bank, initiate the blocking and re-issuance or re-opening of a card or account, and dispute the reimbursement of their monetary losses $[5,6]$. Becoming a fraud victim may also impact customers' perception of feeling secure and protected at their bank.

Copyright @ 2019: This is an open-access article distributed under the terms of the Creative Commons Attribution license which permits unrestricted use, distribution, and reproduction in any medium for non commercial use (NonCommercial, or CC-BY-NC) provided the original author and source are credited. 
Thus, In addressing the existing challenges with identity management, the Central Bank of Nigeria through the Banker' Committee and in collaboration with all banks in Nigeria on February 14, 2014 launched a centralized bank identification system for the banking industry tagged Bank Verification Number (BVN) retrieved from (http://www.cbn.gov.ng). The Bank Verification Number $(B V N)$ is an identification system that gives each bank customer a unique identity across the Nigerian banking industry program forms part of an identity management programme enforced by the CBN which was launched in February 2014, also partly ensuring the effectiveness of Know Your Customer (KYC) principles [7]. The BVN gives each Bank customer a unique identity across the Nigerian Banking industry that can be used for easy identification and verification at Point of Banking operations (Evangelista et al, 2001) Moreover, the Bank Verification Number (BVN) project was introduced due to increasing incidents of compromise on conventional security systems (password and PIN) and a high demand for greater security for access to sensitive or personal information in the Banking System. The major objectives of the initiative are to protect bank customers, reduce fraud and strengthen the Nigerian banking system. Also, the BVN first uses bank information as the means of identifying and verifying all individuals that have accounts in any Nigerian bank, then goes beyond conventional security systems (password and PIN) to give greater security needed to safeguard sensitive personal information in the Banking system, founded on effective bank system in place ensuring an enhanced form of authentication of customers' identity at point of transactions for real-time security process (Financial Industry Bank Verification Number). Also, according to Diamond, 1991, the records gathered from BVN would be used to identify the person afterwards.

In Nigeria, in spite of the banking regulation and bank examination by the Central Bank of Nigeria (CBN), the supervisory role of the Nigeria Deposit Insurance Corporation (NDIC), and The Chartered Institute of Bankers of Nigeria (CIBN), there is still a growing concern about fraud and other unethical practices in the banking industry. Evidence from the NDIC Report 2008 reveals that the report of the examinations and special investigations showed that some banks were still bedeviled with problems of fraud, weak board and management oversight, inaccurate financial reporting, poor book-keeping practices, nonperforming insider-related credits, declining asset quality and attendant large provisioning requirement, inadequate debt recovery, non-compliance with banking laws, rules and regulations, and significant exposure to the capital market through share and margin loans. BVN as it is rightly called in Nigeria has different names in different countries, research revealed that among all the customers using banks, $52 \%$ are located in Asia, Japan has more than an estimated 15 million customers using bank authentication for banking transactions. Banks in Mexico, South-America, Middle-East and Africa are moving towards Bank Verification Number (BVN) or Bank Signature Verification (BSV) because it is believed to be offering more security than traditional Personal Identification Number (PIN). In the developed countries, fraud is not applicable to banks alone and it is not mandated to all customers as it is practiced in Nigeria hence this study.

This study intends to use all the banks in the industry because fraud comes from all the banks in the country irrespective of whether it is prominent or not. However, this study sampled based on stratified sampling method cutting across all sectors in the industry. It is against this background that this study is using the following as samples: 5 Deposit Money Banks, 5 Mortgage Banks, 5 Microfinance Banks, 5 Development Banks

\section{LITERATURE REVIEW \\ Conceptual Review}

Fraud is perhaps the most fatal of all the risks confronting banks. The enormity of bank fraud in Nigeria can be inferred from its value, volume and actual loss. A good number of banks frauds are suppressed partly because of the personalities involved or because of concern over the negative effect such disclosure may have on the image of the bank. Customers may lose confidence in the bank and this could cause a setback in its growth. Fraud leads to loss of money belonging either to the bank or customers. Such losses may be absorbed by the profits for the affected trading period and this, consequently, reduces the amount of profit which would have been available for distribution to shareholders. Losses from fraud, which are absorbed by the equity capital of the bank, impair the bank's financial health and constrain its ability to extend loans and advances for profitable operations. In extreme cases, rampant and large incidences of fraud could lead to a bank's failure. Fraud can increase the operating cost of a bank because of the added cost of installing the necessary machinery for its detection, prevention and protection of assets.

This unproductive diversion of resources reduces outputs and low profits which in turn could retard the growth of the bank. It also leads to a diminishing effect on the asset quality of banks. The problem is more dangerous when compounded by insider loan abuses. Indeed, the first generation of liquidated banks by NDIC was largely a consequence of frauds perpetrated and bank failure.

Furthermore, many factors account for the causes of fraud and fraudulent practices in Nigerian banks. Ojo [8] classifies the causes of fraud and forgeries in banking transactions into two generic factors namely, the institutional or endogenous factors and the environmental or exogenous (social) factors. The institutional factors are weak accounting and internal control system, inadequate supervision of subordinates, disregard for "know your customer (KYC)" rule, poor information technology and data bases management, hapless personnel policies, poor salaries and conditions of service, general frustrations occasioned by management unfulfilled promises, failure to engage in regular call-over, employees "refusal to abide by laid-down procedures without any penalty or sanction, banks" reluctance to report fraud due to the perceived negative publicity or image, banking experience of staff, inadequate infrastructure, inadequate training and re-training, poor book-keeping and genetic traits. The environmental or social factors, according to Idowu [9], are those factors that can be traced to the immediate and remote environment of the bank. These factors of causes, according to Ogbunka [10], are manifest in the penchant to get rich quick, sow and tortuous legal process, poverty and the widening 
gap between the rich and the poor, job insecurity, peer group pressure, societal expectations, increased financial burden on individuals and stiff competition.

\section{Bank Verification Practice in Nigeria}

Biometrics refers to the identification of an individual based on physiological or behavioural traits such as fingerprints, signature amongst others. These technologies have been to analyze human characteristics as an enhanced form of authentication for real-time security processes. Due to the increasing incidents of compromise on conventional security systems (passwords and PIN), there have been high demand for greater security to accessing sensitive or personal information in the Banking System [11]. The Central Bank of Nigeria (CBN) through the Bankers' committee and in collaboration with all banks in Nigeria of February 2014 launched a centralized bank identification system for the banking industry tagged Bank Verification Number (BVN). Bank verification is any means by which an individual or corporate entity can be uniquely identified by evaluating one or more distinguishing biological traits [12]. This unique identifier includes finger prints, hand geometry, earlobe geometry, retina and iris patterns, voice waves, DNA and signatures. Bank Verification has advanced considerably with the advent of computerized database and the digitalization of analogue data, allowing for almost instantaneous personal identification beyond biological traits.

Biometrics is the automated recognition of individuals based on measurable, biological characteristics such as finger prints and iris (eyes) patterns, to identify a person through an electronic device [13]. Biometric recognition provides a strong link between an individual and a claimed identity. The device has been applied with high degree of success in the area of security [14]. In addition to its use, it is useful in issuance of international passport, drivers' license. Hence, it's usage is not alien.

\section{Bank Verification Number and Fraud in Nigerian Banking Industry}

The banking industry has witnessed tremendous changes linked with the development of ICT over the years. The ICT infrastructures used in the banking sector include internet access, internet network which facilitate the operation of Bank Verification Number, automated payment systems among others. The security issue which is the basis of ICT related fraud is of special concern in the banking industry, as banking is highly base on trust from its customers. The risk of hackers, denial of service attacks, technological failures, breach of privacy of customer information, and opportunities for fraud created by the anonymity of the parties to electronic transactions can be managed by enhancing security of information. Depending upon its nature and scope, a breach in security can seriously damage public confidence in the stability of financial institution or of a nation's entire banking industry Agboola [15].

Moreover, banks is expected to strengthen core identity systems such as civil registries and national ID cards serve more functional purposes likely voting, transfers or enabling financial access or health insurance markets, to facilitate developmental interactions and strengthen public accountability" Alan Gelb \& Julia Clark [16]. Also, the International Bank Group International Bank Group 2007 elaborates the importance of high confidence recognition of individuals as citizens, employees, or visitors, as well as in consumer-related applications using the banks technology. Therefore, banks such as voice banks, signature verification, fingerprint, iris scans and face, can be considered for integration in to the current e-banking system to curb fraudulent activities in Nigerian commercial banks. Coventry [17] stresses "the use of a banks security system to confirm the presence of a person potentially reduces the chances of identification or other technological fraud". The choice of a bank for any application depends on its characteristics (e.g. accuracy, cost, speed, robustness to fraudulent methods and attacks etc.) Jain et al., [18].

Bank-recognition systems operate either in user verification or personal identification mode. A user authentication or verification system conducts a one-to-one comparison to determine whether a claimed identify (via a username or identification number) is true or false from a database of authorized users. More so, bank system adopted by Nigerian banks is used for positive recognition, where the aim is to prevent multiple people from using the same identity. On the other hand, a personal identification system conducts a one-to-many comparison to establish an individual's identity from a database of authorized users without the subject having to claim an identity. It is used in negative recognition, where the aim is to prevent a single person from using multiple identities or in positive recognition for user convenience Wayman [19].

It is important to note that the acceptability of the bank technology depends on unimodal or multimodal bank system as it relates to the convenience and speed of authentication. The mode of the bank system will be authentication as reflected by most of the transactions conducted daily.

\section{Information Communication Technology, Bank Verification Number, and Fraud Prevention in Nigerian Banking Industry}

The use of ICT in the strategic management of organizations is nevertheless a new subject on which only few studies have been found [20]. Furrer et al., [21], financial institutions identified the internet as a major opportunity to tackle distribution costs to reengineer the structure of the industry. Biometrics as categorized by Umar et al., can be from physical body regions, medicochemical body features or behavioural traits, defining high (for individuals) to low (for Groups) levels of distinction. Examples of biometrics from body regions include the ocular (iris, retina, sclera vasculature), and (fingerprint, palmprint, finger knuckle print, hand geometry, hand veins) and facial (face, ear shape, teeth); medico-chemical body features include body odour, DNA and heart sound; while behavioural traits include voice, gait, signature. A biometric recognition system is a pattern recognition system that acquires 
biometric data from an individual, extracts a feature set from the acquired data, and compares this feature set with the template set in the database to decide whether to accept (genuine) or reject (impostor) the individual [22].

\section{Theoretical Review}

The following theories were found to be useful and relevant to the study. However of all the theories discussed, this paper is hanging on the Fraud Preventive theory because it is believed it is proposed to curb the behavioural intention of individual.

\section{Fraud Preventative Theory}

Intentions are the best predictor of any planned behavior and understanding the antecedents of intentions provides practical insights into the behavior [23]. Therefore Fraud preventative theory was proposed to curb the behavioral intention of any individual to fraud. According to Goosen, Pampallies, Van der Merwe \& Mdluli [24], a bank owes a duty to its customers to keep accurate records of all the transactions effected against the account in question. Thus, a bank statement serves a vital role in meeting the bank's accountability to its clients, and is a fundamental aspect of modern banking. Goosen et al., [24] state that the role of a bank account statement, which is of the utmost importance to a bank, is that it serves as an audit trail showing in detail the various transactions effected against the account. The Pheiffer [25] defines financial investigations in which, on behalf of law enforcement, financial expertise is used in order to gather, check, refine, process and analyze financial information. According to Tuffey [26], financial investigation is the investigation of an individual or corporation through their financial affairs. Willemse [27] is of the view that financial investigation is the identification and documentation of the movement of money during the course of and after a crime. It establishes the link between where the money comes from, who gets it, when it was received, and where it was stored or deposited. This can provide proof of unlawful activity such as money laundering, racketeering, corruption and terrorist financing, as well as identify and trace assets for asset forfeiture purposes, in effect addressing the proceeds of unlawful activity.

\section{Fraud Management Lifecycle}

The Fraud Management Lifecycle is a network lifecycle where each stage in the lifecycle, is a composite of interrelated, interdependent, and independent actions, functions, and operations. These activities can, but do not necessarily, occur in a sequential or linear flow [27]. The Fraud Management Lifecycle is made up of eight stages: deterrence, prevention, detection, mitigation, analysis, policy, Investigation and prosecution. These stages need to be successfully integrated and balanced so that the benefits of advancements in fraud detection technologies are realized [28, 29]. Effective management of the Fraud Management Lifecycle starts with a common understanding or definition of the stages in the lifecycle. Without this awareness and understanding, fraud management professionals are unlikely to communicate effectively with each other, with their peers in other industries, and within their respective businesses. The terms "lifecycle stage" and "stage" throughout this study are used as a reference to a set of activities. Unlike a traditional linear lifecycle, a network lifecycle's stages are not necessarily linked sequentially, where activities in one stage are completed and then the functioning is passed on to the next stage in the chain. To the contrary, a network lifecycle facilitates simultaneous and sequential actions within each of the lifecycle stages or network nodes. The Fraud Management Lifecycle is, therefore, a network lifecycle where each node in the network, each stage in the lifecycle, is an aggregated entity that is made up of interrelated, interdependent, and independent actions, functions, and operations. These activities can, but do not necessarily, occur in a sequential or linear flow.

\section{Fraud Triangle Theory}

The most widely accepted fraud theory is that offered by Donald Cressey [30], a criminologist who carried out a research on 200 embezzlers (trust violators) who had been incarcerated and held in various prisons in the US Midwest. Cresseys' final research statement was summed up as follows:

"Trusted persons become trust violators when they conceive of themselves as having a financial problem which is nonshareable, are aware that this problem can be secretly resolved by violation of the position of financial trust, and are able to apply to their own conduct in that situation verbalizations which enable them to adjust their conceptions of themselves as trusted persons with their conceptions of themselves as users of the entrusted funds or property" [31]. He stated further that fraud is a crime that is more costly than most people realized, when businesses and organization understand the fraud triangle they can more effectively combat behavior that negatively impacts their operations. There are three factors that make up fraud triangle: 


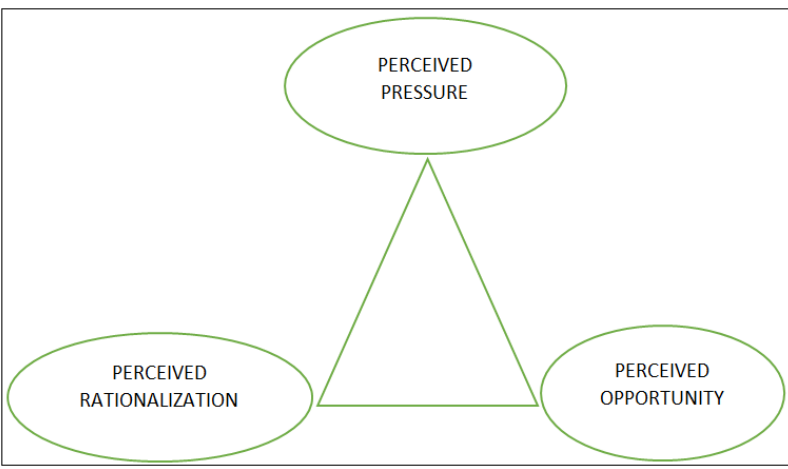

The Fraud Triangle, (1953)

Source: Wells, Joseph T. (1997) [3. Occupational Fraud Abuse. In Albrecht, W. Steve (Ed.). Fraud Examination. Thomson: South-Western Publishing, 2003

\section{Pressure}

Most individual require some form of pressure to commit a criminal act. This pressure does not need to necessarily make sense to outside observers, but it does not need to be present. Pressure includes money problem, gambling debts, alcohol or drug addiction, overwhelming medical bills. Greed can also become a pressure but it usually needs to be associated with injustice.

\section{Rationalization}

The mindset of a person about to commit an unethical act is one of rationalization. The individual managers to justify what he or she is about to do. Some may think they are just going to borrow the stolen goods or that they need money than the company they are stealing from.

\section{Opportunity}

This means that one's socio-economy environment serves to predetermine their likelihood of achieving unethical financial success through legitimate and illegitimate means. Cressey put forward the fact that all people have opportunity to commits fraud against third parties, employees, suppliers and customers of the employers.

\section{Empirical Review}

Farhana and Suraiya [33] studied Bank Signature Verification and performance of some selected banks in India. He examined a sample of 45 banks, which was aimed at explaining the techniques and variations used to implement a full proof signature verification system. Arifin [34] also examined the impact of Bank on performance of Banks in Japan and stated that many banks nationwide are already using Bank verification to authenticate employees and customers. Bhavana [35] opined in his study on significance of bank verification and authentication in Australia and issues of success factor surrounding bank especially in the context of user authentication and verification control in the banking sector. Mark [36] carried out an empirical study about the benefits of introducing bank verification in South Africa. Much analysis was done on authentication and verification of customers' bio-data in other to guide against identity theft, blacklisted customers, and to enhance financial inclusion.

\section{METHODOLOGY}

The aim of this research is to examine the role ICT, BVN in preventing fraudulent activities in Nigerian Banking Industry. Data were collected from primary source through the administration of questionnaire on 250 respondents which is appropriate according to Kaiser Criterion [37]. The selected banks included a fraction all banks in the country from the Deposit Money Banks, Development Banks, Microfinance Banks, Bank of Industry, Bank of Agriculture to Mortgage Banks. It is believed that fraud are perpetrated not only in the deposit money banks but all other forms of banks experience this incidence of fraud. The questionnaire consisted of four sections: Section A elicited information on respondents' profile, followed by information on effectiveness of Information and communication technology (ICT), Bank Verification Number (BVN) to prevent fraudulent practices in Nigerian Banks in section B. Section C dealt with Effects of Information and communication technology, Bank Verification Number on Fraud Prevention and finally questions on Challenges faced with the adoption of Bank Verification Number. The respondents were asked to indicate their opinion using the likert scale of 1 to 5 (where 1 represent Strongly Disagree, 2 represents Disagree, 3 represents Undecided, 4 represents Agree and 5 represents Strongly Agree). 


\section{RESULTS AND DISCUSSION}

Table-1: Model Summary

\begin{tabular}{|l|l|l|l|l|}
\hline Model & $\mathbf{R}$ & $\mathbf{R}$ Square & Adjusted R Square & Std. Error of the Estimate \\
\hline 1 & $.177^{\mathrm{a}}$ & .031 & .022 & 1.20615 \\
\hline $\begin{array}{l}\text { a. Predictors: (Constant), BVN is very effective in preventing fraud in the Nigerian Banking system, Cooperation among financial } \\
\text { institution can help reduce fraud in the bank to the barest minimum }\end{array}$ \\
\hline
\end{tabular}

The coefficient of determination $R^{2}$ is relatively low with a value of $17.7 \%$ suggesting that there more many uncovered variables that actually prevent fraud than BVN. However, the $\mathrm{R}^{2}$ signifies that BVN can actually predict the change in fraud in the banking sector for about $17.7 \%$.

Table-2: ANOVAa

\begin{tabular}{|l|l|l|l|l|l|l|}
\hline \multicolumn{2}{|l|}{ Model } & Sum of Squares & df & Mean Square & F & Sig. \\
\hline \multirow{3}{*}{1} & Regression & 10.392 & 2 & 5.196 & 3.572 & $.030^{\mathrm{b}}$ \\
\cline { 2 - 7 } & Residual & 322.968 & 222 & 1.455 & & \\
\cline { 2 - 7 } & Total & 333.360 & 224 & & & \\
\hline \multicolumn{2}{|l|}{ a. Dependent Variable: With the introduction of BVN, customers account are protected from unauthorized access } \\
\hline $\begin{array}{l}\text { b. Predictors: (Constant), BVN is very effective in preventing fraud in the Nigerian Banking system, Cooperation among financial } \\
\text { institution can help reduce fraud in the bank to the barest minimum }\end{array}$
\end{tabular}

The F statistics value of 3.572 is significant at $5 \%$ implying that there is significant relationship between BVN and fraud prevention in the Nigeria Banking system. Although, as explained earlier, the high residuals value signifies that more uncovered variables significantly explained fraud prevention in the banking sector than BVN.

Table-3: Coefficients ${ }^{a}$

\begin{tabular}{|c|c|c|c|c|c|c|}
\hline \multirow{2}{*}{\multicolumn{2}{|c|}{ Model }} & \multicolumn{2}{|c|}{$\begin{array}{l}\text { Unstandardized } \\
\text { Coefficients }\end{array}$} & $\begin{array}{l}\text { Standardized } \\
\text { Coefficients }\end{array}$ & \multirow[t]{2}{*}{$T$} & \multirow[t]{2}{*}{ Sig. } \\
\hline & & \multirow{2}{*}{$\begin{array}{l}\text { B } \\
2.589\end{array}$} & \multirow{2}{*}{$\begin{array}{l}\text { Std. Error } \\
.313\end{array}$} & \multirow[t]{2}{*}{ Beta } & & \\
\hline 1 & (Constant) & & & & 8.277 & .000 \\
\hline & $\begin{array}{l}\text { Cooperation among financial institution can help } \\
\text { reduce fraud in the bank to the barest minimum }\end{array}$ & .197 & .076 & .173 & 2.613 & .010 \\
\hline & $\begin{array}{l}\text { BVN is very effective in preventing fraud in the } \\
\text { Nigerian Banking system }\end{array}$ & .015 & .029 & .036 & .539 & .591 \\
\hline
\end{tabular}

The results of this study revealed that the cooperation among financial institution can help reduce fraud in the bank to barest minimum and this has positive significant effect on BVN and protection of customers account. Similarly, BVN is very effective in preventing fraud in the Nigerian Banking system and can positively influence customer account protection from unauthorized access.

Table-4: Model Summary

\begin{tabular}{|l|l|l|l|l|}
\hline Model & $\mathbf{R}$ & $\mathbf{R}$ Square & Adjusted R Square & Std. Error of the Estimate \\
\hline 1 & $.173^{\mathrm{a}}$ & .030 & .026 & 1.20423 \\
\hline \multicolumn{2}{|l|}{ a. Predictors: (Constant), Cooperation among financial institution can help reduce fraud in the bank to the barest minimum } \\
\hline
\end{tabular}

The coefficient of determination $R^{2}$ is relatively low with a value of $17.3 \%$ suggesting that there more many uncovered variables that actually prevent fraud than BVN. However, the $\mathrm{R}^{2}$ signifies that BVN can actually predict the change in fraud in the banking sector for about $17.3 \%$.

\begin{tabular}{|c|c|c|c|c|c|c|}
\hline \multicolumn{7}{|c|}{ ANOVA $^{a}$} \\
\hline \multicolumn{2}{|c|}{ Model } & Sum of Squares & df & Mean Square & $F$ & Sig. \\
\hline \multirow[t]{3}{*}{1} & Regression & 9.970 & 1 & 9.970 & 6.875 & $.009 \mathrm{~b}$ \\
\hline & Residual & 323.390 & 223 & 1.450 & & \\
\hline & Total & 333.360 & 224 & & & \\
\hline \multicolumn{7}{|c|}{ a. Dependent Variable: With the introduction of BVN, customers account are protected from unauthorized access } \\
\hline \multicolumn{7}{|c|}{ b. Predictors: (Constant), Cooperation among financial institution can help reduce fraud in the bank to the barest minimum } \\
\hline
\end{tabular}

The F statistics value of 6.875 is significant at $5 \%$ implying that there is significant relationship between Cooperation among financial institution can help reduce fraud in the bank to the barest minimum and introduction of BVN. Although, as explained earlier, 
the high residuals value signifies that more uncovered variables significantly explained fraud prevention in the banking sector than BVN.

\begin{tabular}{|c|c|c|c|c|c|c|}
\hline \multicolumn{7}{|c|}{ Coefficients $^{a}$} \\
\hline \multirow{2}{*}{\multicolumn{2}{|c|}{ Model }} & \multicolumn{2}{|c|}{$\begin{array}{l}\text { Unstandardized } \\
\text { Coefficients }\end{array}$} & $\begin{array}{l}\text { Standardized } \\
\text { Coefficients }\end{array}$ & \multirow[t]{2}{*}{$T$} & \multirow[t]{2}{*}{ Sig. } \\
\hline & & B & Std. Error & Beta & & \\
\hline \multirow[t]{2}{*}{1} & (Constant) & 2.647 & .293 & & 9.022 & .000 \\
\hline & $\begin{array}{l}\text { Cooperation among financial institution can help } \\
\text { reduce fraud in the bank to the barest minimum }\end{array}$ & .198 & .075 & .173 & 2.622 & .009 \\
\hline
\end{tabular}

The results of this study revealed that the cooperation among financial institution can help reduce fraud in the bank to barest minimum and this has positive significant effect on BVN and protection of customers account.

\section{Concluding Remarks}

The introduction Bank Verification Number is an effective tool that will reduce the incidence of fraud to the barest minimum in Nigeria. The BVN coupled with the equipment needed to effectively put its use to shape when no default is observed will greatly improve the confidence of the public. The financial institutions and their business partners must continue to seek and develop new solutions to the issue of customer authentication and transaction validation.

Some of the applications are very effective when used by one institution. However, many of these applications, though effective as a singular institutional solution, may become many times more powerful when adopted as an overall industry approach to solving the issues of customer authentication.

A financial institution can take advantage of the proximity of the communication to validate the customer's identity by utilizing of one of the following: what the person knows - a combination of both "in wallet" information such as social security number or "out of wallet" information such as the name of an old pet what the person has - a token that generates random numbers and is synchronized with the authentication program or a private key that encrypts the transaction so that only a corresponding public key can decrypt it; and, who the person is - utilizing banks to confirm an identity by comparing physical characteristics to those on file.

Sharing information about fraudulent activity, controlling fraud, particularly that fraud associated with falsified customer identity, can be more effective if it addressed at the origination of the payment process .Bank verification is no longer the sole province of the paying institution. In the new financial services paradigm, it is responsibility of all participants in the payments system. The use of ICT and BVN will bring about the following effectiveness in reducing fraud and fraudulent practices:

- Automation, which can reduce opportunities for occurrence of corruption in repetitive operations

- Detection in operations, to identify anomalies, outliers and underperformance

- Awareness raising, to empower the public and inform them of their rights to resist arbitrary treatments

- Transparency, which can help reduce rooms for indiscretion

- Reporting, to create compliant channels that can lead to concrete action and help punish violators and close loopholes

APPENDIX I

\section{QUESTIONNAIRE \\ INFORMATION AND COMMUNICATION TECHNOLOGY, BANK VERIFICATION NUMBER AND FRAUD PREVENTION IN NIGERIAN DEPOSIT MONEY BANKS}

\section{SECTION A}

\section{BACKGROUND INFORMATION/DEMOGRAPHIC CHARACTERISTICS}

Please kindly tick ( ) your answer in the appropriate boxes

Age: 20 years or below ( ) 21-30 yrs (

Sex: $\quad$ Male ()

Female ()

2.

Educational Qualification: SSCE/ND/NCE ( )

$31-40$ yrs ( )

41-50 yrs ( ) 50 years and above ( )

3. Educational Qua

4. Years of Working Experience

5. Job Title:

6. Current Position/Rank: 


\section{SECTION B}

This section deals with the Effectiveness of Information and Communication Technology, Bank Verification Number (BVN) to prevent fraudulent practices in Nigerian Banks. Each question contains appropriate alternatives to choose which is most suitable to you as a respondent

\begin{tabular}{|l|l|l|l|l|l|l|}
\hline S/N & QUESTION & $\begin{array}{l}\text { SA } \\
\text { (5) }\end{array}$ & $\begin{array}{c}\text { (4) } \\
\text { (4) }\end{array}$ & $\begin{array}{l}\text { (3) } \\
\text { (2) }\end{array}$ & $\begin{array}{l}\text { SD } \\
\text { (1) }\end{array}$ \\
\hline 1 & With the introduction of BVN, customers account are protected from unauthorized access & & & & & \\
\hline 2 & BVN can be used to address the issue of identity theft & & & & & \\
\hline 3 & BVN has reduced the likelihood of fraud since its introduction & & & & \\
\hline 4 & BVN is very effective in preventing fraud in the Nigerian Banking system & & & & \\
\hline 5 & BVN can be used to get the blacklisted customers & & & & \\
\hline 6 & ICT is very effective in the proper functioning of BVN to detect and prevent fraud & & & & & \\
\hline
\end{tabular}

\section{SECTION C}

Prevention

This section deals with the Effects of Information and Communication Technology, Bank Verification Number on Fraud

\begin{tabular}{|c|c|c|c|c|c|c|}
\hline $\mathrm{S} / \mathrm{N}$ & QUESTION & SA & A & U & D & SD \\
\hline 1 & BVN has making a significant impact in reducing fraud & & & & & \\
\hline 2 & BVN gives a unique identity that can be verified across Nigerian Deposit Money Banks & & & & & \\
\hline 3 & The customer's unique number is used to check customer's status with other banks & & & & & \\
\hline 4 & BVN increases customer's satisfaction and confidentiality & & & & & \\
\hline 5 & BVN reduces the risk of non-performing loans across banks & & & & & \\
\hline 6 & The use of ICT and BVN is the most effective tool in preventing fraud & & & & & \\
\hline
\end{tabular}

\section{SECTION D}

This section will address the various Challenges faced with the adoption of Bank Verification Number

\begin{tabular}{|l|l|l|l|l|l|l|}
\hline S/N & QUESTION & $\begin{array}{c}\text { SA } \\
\text { (5) }\end{array}$ & $\begin{array}{l}\text { A } \\
\text { (4) }\end{array}$ & $\begin{array}{l}\text { (3) } \\
\text { (3) }\end{array}$ & $\begin{array}{l}\text { D } \\
\text { (2) }\end{array}$ & $\begin{array}{c}\text { SD } \\
\text { (1) }\end{array}$ \\
\hline 1 & Cooperation among financial institution can help reduce fraud in the bank to the barest minimum & & & & & \\
\hline 2 & BVN has reduced cybercrime compared to before its introduction & & & & & \\
\hline 3 & $\begin{array}{l}\text { Development of comprehensive internet legislations helps to regulate electronic financial } \\
\text { transaction }\end{array}$ & & & \\
\hline 4 & $\begin{array}{l}\text { Absence of centralized electronic databank containing specific information on each individual } \\
\text { hinders the implementation of BVN }\end{array}$ & & & & \\
\hline 5 & Encryption and other online securities hinders the success of BVN & & & & \\
\hline 6 & ICT aids fraud perpetration & & & \\
\hline
\end{tabular}

APPENDIX II

Model Summary

\begin{tabular}{|l|l|l|l|l|}
\hline Model & R & R Square & Adjusted R Square & Std. Error of the Estimate \\
\hline 1 & $.037^{a}$ & .001 & -.003 & 1.22181 \\
\hline \multicolumn{2}{|l|}{ a. Predictors: (Constant), BVN is very effective in preventing fraud in the Nigerian Banking system } \\
\hline
\end{tabular}

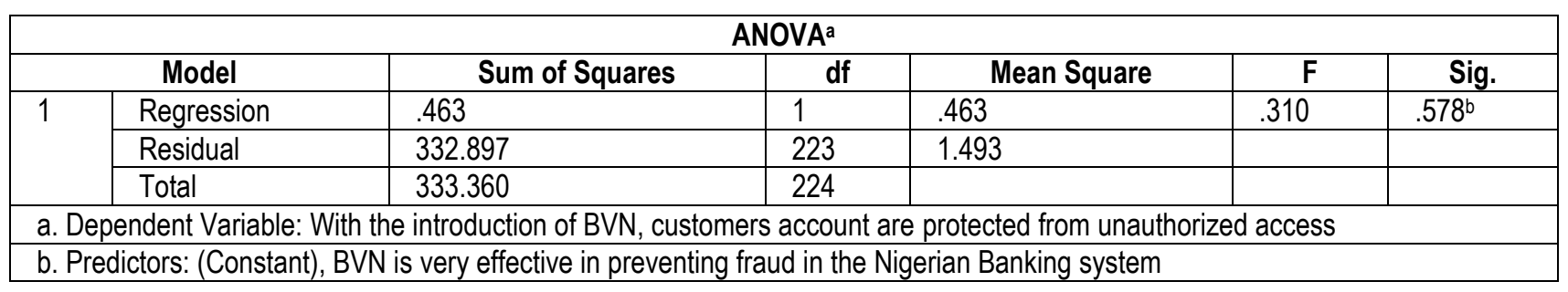

\begin{tabular}{|c|c|c|c|c|c|c|}
\hline \multicolumn{7}{|c|}{ Coefficients ${ }^{\mathrm{a}}$} \\
\hline \multirow{2}{*}{\multicolumn{2}{|c|}{ Model }} & \multicolumn{2}{|c|}{$\begin{array}{l}\text { Unstandardized } \\
\text { Coefficients }\end{array}$} & $\begin{array}{l}\text { Standardized } \\
\text { Coefficients }\end{array}$ & \multirow[t]{2}{*}{$T$} & \multirow[t]{2}{*}{ Sig. } \\
\hline & & $B$ & Std. Error & Beta & & \\
\hline 1 & (Constant) & 3.325 & .138 & & 24.101 & .000 \\
\hline & $\begin{array}{l}\text { BVN is very effective in preventing fraud in the Nigerian } \\
\text { Banking system }\end{array}$ & .016 & .029 & .037 & .557 & .578 \\
\hline
\end{tabular}




\section{REFERENCE}

1. Ogechukwu, A. D. (2013). The current ethical challenges in the Nigerian commercial banking sector. Global Journal of Management And Business Research.

2. Adeyemo Kingsley, A. (2012). Frauds in Nigerian banks: Nature, deep-seated causes, aftermaths and probable remedies. Mediterranean Center of Social and Educational Research, 3, 279.

3. Agwu, E. M. (2013). Cyber criminals on the internet super highways: A technical investigation of different shades and colours within the Nigerian cyber space. International Journal of Online Marketing, 3(2): 56-74.

4. Gates, T., \& Jacob, K. (2009). Payments fraud: prevention versus reality - a conference summary. Economic perspective, 33(1), 7-15.

5. Bowen, S., Chawla, N., Collins, S. E., Witkiewitz, K., Hsu, S., Grow, J., ... \& Marlatt, A. (2009). Mindfulness-based relapse prevention for substance use disorders: A pilot efficacy trial. Substance abuse, 30(4), 295-305.

6. Malphrus, S. (2009). Perspectives on retail payments fraud. Perspectives on Retail Payments Fraud (February 11, 2009). Economic Perspectives, 33(1), 31-36.

7. Abata, M. A. (2014). Asset quality and bank performance: A study of commercial banks in Nigeria. Research Journal of Finance and Accounting, 5(18), 39-44.

8. Ojo, K. K., Gillespie, J. R., Riechers, A. J., Napuli, A. J., Verlinde, C. L., Buckner, F. S., ... \& Wells, T. N. (2008). Glycogen synthase kinase 3 is a potential drug target for African trypanosomiasis therapy. Antimicrobial agents and chemotherapy, 52(10), 3710-3717.

9. Abiola, I. (2009). An assessment of fraud and its management in Nigeria commercial banks. European Journal of Social Sciences, 10(4), 628-640.

10. Ogbunka, N. M (2002). Risk and internal control. Management in financial institutions, 187-188

11. Ekomwenrenren, I., \& Ekuobase, G. (2016). Curbing Corruption in Nigeria using Service Innovation. A Multidisciplinary Journal Publication of the Faculty of Science, Adeleke University, Ede, Nigeria.

12. Awe, T. J., Peterson, K. J., Yu, E. P., McBride, R. D., Sinars, D. B., Gomez, M. R., ... \& Sefkow, A. B. (2016). Experimental demonstration of the stabilizing effect of dielectric coatings on magnetically accelerated imploding metallic liners. Physical review letters, 116(6), 065001.

13. National Research Council. (2010). Excellence in Research for Australia 2010: national report.

14. Hall, C. M. (2008). Tourism planning: Policies, processes and relationships. Pearson Education.

15. Agboola, A. A. (2001). Impact of Electronic Banking on Customer Services in Lagos, Nigeria in Ife. Journal of Economics and Finance. Department of Economics, 5(1), 8-12.

16. Gelb, A., \& Clark, J. (2013). Identification for development: The biometrics revolution. Center for Global Development Working Paper, (315).

17. Coventry, L. (2005). Usable banks offer a technological solution to the authentication of individuals. Dundee, UK: Advanced technology and research, NCR financial solutions.

18. Jain, A.K., Ross, A., \& Pankanti, S. (2006). Banks: A tool for information security. IEEE transaction on information forensics and security, 1(2)

19. Wayman, J. L. (2001). Fundamentals of biometric authentication technologies. International Journal of Image and Graphics, 1(01), 93-113.

20. Edwin, M. E., Atuma, O., Aigbiremolen, O. M., \& lyoha, O. F (2014). The Impact of ICT in the Strategic Management of Financia Institutions. International Review of Management and Business Research, 3(3).

21. Furrer, R., \& Bengtsson, T. (2007). Estimation of high-dimensional prior and posterior covariance matrices in Kalman filter variants. Journal of Multivariate Analysis, 98(2), 227-255.

22. Jain, A. K., Ross, A., \& Prabhakar, S. (2004). An Introduction to Biometric Recognition. IEEE Transaction on circuits and systems for video technology. Special Issue on Image and Video-Based Biometics, 14(1): 4-20

23. Aizen, I., \& Fishbein, M. (1980). Understanding attitudes and predicting social behaviour.

24. Goosen, W., Pampallis, A., Van Der Merwe, A., \& Mdluli, L. (1999). Banking in the new millennium. Juta and Company Ltd.

25. Pheiffer, C. P. (1998). The role of steroidogenic factor-1 (SF-1) in gonadotropin-releasing hormone (GnRH) receptor gene regulation (Doctoral dissertation, University of Cape Town).

26. Tuffey, S., \& Riewald, S. (2002). Feature: Plyometrics.

27. Willemse, B. W., Postma, D. S., Timens, W., \& ten Hacken, N. H. (2004). The impact of smoking cessation on respiratory symptoms, lung function, airway hyperresponsiveness and inflammation. European Respiratory Journal, 23(3), 464-476.

28. McRae, R., \& Hubert, D. (2001). Human security and the new diplomacy: Protecting people, promoting peace. McGill-Queen's Press-MQUP.

29. Carminati, M., Giusti, S., Hausdorf, G., Qureshi, S., Tynan, M., Witsenburg, M., ... \& Ovaert, C. (2000). A European multicentric experience using the CardioSEAL $®$ and Starflex double umbrella devices to close interatrial communications holes within the oval fossa. Cardiology in the Young, 10(5), 519-526.

30. Cressey, D. R., \& McDermott, R. A. (1973). Diversion from the juvenile justice system (Vol. 42, No. 12). Ann Arbor: National Assessment of Juvenile Corrections, University of Michigan.

31. Cressey, D. R. (1953). Other people's money; a study of the social psychology of embezzlement.

32. Wells, J. T. (1997). Occupational fraud and abuse. Obsidian Publishing Company. 
33. Jabin, S., \& Zareen, F. J. (2015). Biometric signature verification. International Journal of Biometrics, 7(2), 97-118.

34. Arifin, H. (2014). Impact of bank verification in banking industry. Right punch publication journal, Indian, 6(270).

35. Bhavana, D. (2013). Signature scrutiny system in banking application. Journal of business education, 2(3).

36. Mason, M. (2010, August). Sample size and saturation in $\mathrm{PhD}$ studies using qualitative interviews. In Forum qualitative Sozialforschung/Forum: qualitative social research, 11(3).

37. Field, S. (2005). Screenplay: The foundations of screenwriting. Delta. 